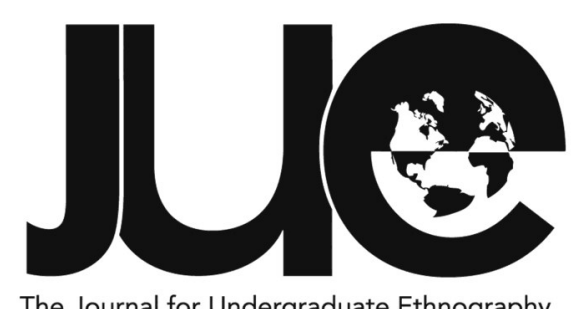

\title{
School Without Racism? How White Teachers in Germany Practice Anti-Racialism
}

\section{Hanna Maria Burhoff}

University College Maastricht, hanna.burhoff@posteo.de

\section{ABSTRACT}

This qualitative study investigates how white teachers at a German Catholic comprehensive school conceptualize issues of "race" and racism in the context of being a "School without Racism - School with Courage" (SOR-SMC). By collecting signatures and exhibiting yearly projects, more than 3,300 schools in Germany brand their school to be "without racism". I found the branding of my researched school to be a form of "anti-racialism" that opposed "race" and racism as concepts but did not tackle any underlying racist structures (Goldberg 2009, 10). The teachers I interviewed took the SOR-SMC branding for granted and assumed that the school was racism-free. They thereby engaged in silent racism and reproduced racist connotations and structures without challenging them (Trepagnier 2001). Being anti -racist is not accomplished by declaring a school as racism-free. Instead, white teachers need to understand that anti-racism involves a deeper engagement with the structures that keep "racial" inequality in place (Goldberg 2009, 10).

Keywords: whiteness; racism; critical race theory; identity; Germany; education 
There are no schools without racism (yet). But together we can change this. By looking closely instead of looking away. And by recognizing that a label might be a (good) beginning but is not yet enough to eliminate a social problem. (Ogette 2016, 111)

W ith these words, the German antiracism activist and educator Tupoka Ogette (2016) questioned the potential of the Schule ohne Rassismus - Schule mit Courage or "School without Racism - School with Courage" (SOR-SMC) branding. The above quote is from her book "Exit Racism", a guide for white people to understand and unlearn racism as it is engrained in German society. Ogette (2016) emphasized that no matter the branding of the school, schools are still shaped and impacted by structural and institutional racism. Therefore, she warned that anti-racism needs to involve more than just a label. Otherwise, participating schools run the risk of ignoring the issue instead of tackling it.

More than 3,300 schools in Germany are branded as SOR-SMC (Aktion Courage e.V. n.d.b). Signs at their entrances and yearly projects highlight the schools' opposition to racism. The concept behind SOR-SMC can be traced back to the German registered association Aktion Courage e.V. (Action Courage). It was initiated in 1995 as a response to violent forms of racism that arose in Germany in the 1990s, whereby people of color in various German cities were killed. The racist murders created a pogrom-like atmosphere in Germany which was characterized by right-wing extremists (Fuchs and Frey 2010). Consequently, the initiators of the SOR-SMC project saw a need to "overcome intolerance and hatred" at German schools (Aktion Courage e.V. n.d.-c, n.p.).
Lately, the violent presence of racism in Germany was highlighted by racist acts such as the terrorist attack in Hanau in February 2020 where nine people of color were killed, or the attempted mass murder of Jews in Halle (Saale) in 2019 (Kaschel 2020). In its institutionalized form, racism is visible in the labor market through lower employment rates of people "with a migration background" as well as through their reported experiences of "racial" discrimination (ENAR European Network Against Racism 2017). But already in early education, students of a lower social class and students "with a migration background" are systemically inclined to graduate with lower degrees from German schools (Klemm 2007; Wellgraf 2014). Knowing about this institutional discrimination, I was interested in understanding how white teachers make sense of their role and responsibility at a German school that brands itself to be "without racism".

I chose the Happiness School (a pseudonym), a Catholic secondary school in a city in West Germany, as the subject of this study. Its unique status as private school allows for a specific selection of students that fit the pedagogical profile as defined by the Catholic diocese. The Happiness School has a Catholic orientation and focuses on an open and peaceful learning environment to distinguish its profile from public schools. This exacerbates the students' demographic homogeneity, making it a particularly interesting case to study the teachers' sense of their roles and responsibilities. Since 2013, the school has branded itself as a "School without Racism School with Courage" and exhibits yearly projects to maintain this status. To understand how the white teachers at the Happiness School make sense of being a SOR-SMC, the guiding question of my research was: How do white teachers at a German Catholic comprehensive school conceptualize issues of "race" and racism in the context of being a "School without Racism - School with Courage" (SOR-SMC)? To explore this issue, I interviewed nine white teachers at the Happiness School and contextualized their experiences within the European discourse on "race" and racism.

Before going further, I need to explain some of the terminology of "race" that I am using. I use quotation marks around the word "race", to 
emphasize that it is a social construction, an "abstract signifier for separating human groups socially, politically and economically" (Lentin 2008, 490). I use "people of color" throughout the paper to describe "all members of racialized and marginalized communities" that experience oppression through the dominant white culture (Ha 2009, n.p.). Finally, the phrase "with a migration background" is common in German to describe people who are perceived as nonGerman and non-white. An exact translation of the German "mit Migrationshintergrund" would be "with migration background".

In this article, I begin by explaining my theoretical framework of structural and institutional racism, the European discourse on "race" and racism, and critical whiteness at schools. Next, I introduce the Happiness School and explain my methodology. The analysis has three components. First, I reevaluate the consequences of branding a "School without Racism - School with Courage". Secondly, I reflect upon the teachers' approach to "race" and their perceptions of students of color. Thirdly, I address the teachers' relationship to whiteness and their responsibility as white educators. Finally, I discuss the main contradictions that I found.

\section{Anti-Racialism vs. Anti-Racism}

To understand the branding "School without Racism", it is important to differentiate between "anti-racialism" and "anti-racism" (Goldberg 2009). While the latter is an opposition to conditions of "racial" inequality and includes the risk and willingness to give up on societal structures that perpetuate marginalization, "anti-racialism" is the opposition to "a concept, a name, a category, a categorization" (Goldberg 2009, 10). "Anti-racialism" therefore is the superficial critique of racism, without any clear indication on how to challenge a racist system. It criticizes an essentialist argument about "race", without interrogating institutionalized and structural forms of racism as they are manifested in society. "Anti-racialism" erases "race" from the discourse "without addressing the legacy, the roots, the scars of racisms' histories, the weights of race" (Goldberg 2009, 21).
The European conceptualization of racism is illustrative of anti-racialism. The Holocaust was taken as the marking point and an antithesis to European modernity, while a prevention of its repetition was emphasized (Goldberg 2006). In the attempt to overcome Europe's cruel and racist past, "race" disappeared from the public discourse and racism was pushed to the periphery (Lentin 2008; Müller 2011). As such, racism was framed as an issue that occurred outside of Europe, something only other societies struggled with (Goldberg 2006). With this silence about "race" it was assumed that any structural discrimination based on "race" would also disappear (Lentin 2008). This, however, is a form of anti-racialism, where the concept of "race" was erased only to be replaced by "culture", "ethnicity" or "background", all of which maintain a racist structure.

Despite the silence about "race", European identity is based on a "racialized" ideal of "whiteness" (El-Tayeb 2011). "Racial" differences are created, and minorities are framed as the Other, the non-European. In the German context, this is visible through the association of Germanness with whiteness (Müller 2011). Furthermore, even in a context that promotes "racial" equality, differences can be emphasized so as to problematize them. In her qualitative study on diversity in the workplace, which she frames as "ethnic", van den Broek (2014) described mechanisms that distorted white people's perception and that rendered ethnical differences as "bad". She thereby highlighted the dichotomy between the wish for diversity on the one hand, and the preference for sameness on the other. Ultimately, van den Broek's study showed how the ideology of "racial" equality can be upheld in the European context, even when people perpetuate the idea of a "racialized" Other.

\section{Critical Whiteness Studies}

Critical whiteness studies investigates the position of white people in a racist system that serves their advantage. Frankenberg (1993) emphasized that although whiteness is seen as a neutral category and goes unnoticed, "race" nevertheless shapes the lives of white people as members of a racist system. The first comprehensive work that introduced a critical 
perspective on the white subject and emphasized the contributions of artists and academics of color in Germany was published by Eggers et al. (2005). However, the authors emphasized that the topic had not reached the German public discourse. White Germans still tend to have an old perception of whiteness as associated with Nazis and white supremacy (Müller 2011, 620).

Critical whiteness scholars such as Robin DiAngelo (2016) and Barbara Applebaum (2004) highlighted the importance of the classroom as a place of confrontation with issues of "race" and racism. They addressed white teachers' and students' difficulties in understanding and explaining racism. Picower (2009) also found that due to white privilege, the teachers' "racialized" position can go unnoticed. Instead, white teachers reinforce a racist discourse through emotional, ideological and performative strategies such as expressing fear in situations with students of color. This especially affects students of color negatively as it maintains "racial" inequality. Consequently, Picower (2009) emphasized the importance of critical race education for white teachers because of their responsibility as educators.

German schoolbooks perpetuate a racist discourse that reinforces stereotypes (Apraku 2017; Marmer and Sow 2015) while teachers "with a migration background" report experiences of exclusion and discrimination at German schools (Fereidooni 2016). These are only two examples of the institutionalization of racism at schools. Institutionalized discrimination based on "race" presupposes that the schools' organizational structures legitimize certain racist knowledge and practices (Gomolla and Radtke 2009). Often these are subtle and engrained in the organization's mechanics so that individual members are unaware of them. As various studies have shown, German schools produce "racial" differences and exacerbate the segregation of students in primary schools (Gomolla and Radtke 2009; Radtke 2007). Through a specific pedagogical profile, schools can additionally attract and select certain students, leading to an increased homogeneity of their school community (Radtke 2007). As members of the school as an institution, teachers contribute to the legitimization of racist practices. It therefore appears crucial to investigate whether white teachers at a private SOR-SMC are reflective of the racist structures at their school and to analyze how they make sense of their responsibility as educators.

\section{The Happiness School}

The school I studied is located in a city in NorthRhine-Westphalia, Germany. In 2018, the percentage of people 'with a migration background' resembled roughly the national average of 26\% (Bundesamt für Migration und Flüchlinge 2019). The city is politically shaped by the Christian Democratic Union (CDU), and its social composition is impacted by the university. The Happiness School is a Catholic comprehensive secondary school, integrating the three traditional secondary school tracks of the German educational system in one institution. It was the first and until recently the only comprehensive school in this city, founded in 1969, and it has a very prestigious reputation, leading to disproportionately more applications than open spots for new students. As a private Catholic school, the Happiness School can form a unique pedagogical profile and attract and select specific staff and students. Consequently, the homogeneity of "race", social background, religious orientation, and performance of the students is intensified. In 2019/2020, 3.5\% of the students had a non-German citizenship, which is below the city-wide average of $10 \%$ but gives no clear indication on the number of students of color, since nationality is not an indication of "race". It was a general assumption among the teachers that the majority of the students and staff at the Happiness School were white. The Happiness School requests no tuition fees, but instead benefits from the financial support of the diocese that offers more opportunities than public schools can.

\section{Methodology}

This qualitative, exploratory study aimed to understand how white teachers at a German Catholic comprehensive school conceptualize issues of "race" and racism in the context of being a "School without Racism - School with Courage" (SOR-SMC). I chose a critical paradigm to deconstruct how the teachers make sense of their social position and responsibility in regard to racism (Hesse-Biber and Leavy 2006). To 
collect rich, in-depth accounts of the teachers' perspectives, I utilized semi-structured interviews (Gray 2014; Hesse-Biber and Leavy 2006). The results provide an account of situated knowledge, which is shaped by the sociopolitical position of the interviewees and is therefore specific to the context (Hesse-Biber and Leavy 2006).

I contacted all employees who were teaching at least one of the three subjects: History, Social Sciences/Politics, or English at the Happiness School via email. This purposive sampling yielded nine participants, including two teachers who were involved in the SOR-SMC project. To preserve their anonymity, I changed the teachers' names. All teachers self-identified as white Germans. There were four men and five women, and their ages ranged between 29 and 65 years. Some participants had only recently started working at the Happiness School, while one had been around since the 1980s.

The interviews took place via Skype, by phone or in person and lasted between 45 and 80 minutes. I asked questions about the teachers' experiences of racism at the school and in Germany, their understanding of the SOR-SMC label and projects, and their views on critical whiteness. With the interviewees' consent, I audiotaped and transcribed their answers. I focused on the spoken words, but also included stumbling, laughter and other verbal signs. To interpret and analyze the data, I made use of coding and memo writing in line with a "thematic analysis" (Gray 2014). Starting with open coding using the software ATLAS.ti (Version 8.4.2 Mac), I looked for similarities and ambiguities across the transcripts. Through memo writing I could express the connections among the emerging codes, formulate them more analytically, and begin with the interpretation of the data (Hesse-Biber and Leavy 2006). This process was significantly informed by already established theories, thereby ensuring the reliability of my interpretation. Based on the memos, I developed a number of main themes which are presented in the remainder of this paper as the research results.

As a white German who grew up in a city with similar demographics, I could share certain experiences with the interviewees and experienced how "race" and racism were approached at a German school in a predominantly white environment. While I could comprehend the teachers' standpoint, I could also distance myself from it. Over the past three years I lived in the Netherlands and enjoyed university education about critical race theory and whiteness studies. I could therefore recount many experiences that the interviewees mentioned as my own, but my academic position allowed me to interpret them differently. At times, I shared my analysis of the situation and gave an account of how I understood racism or whiteness, making my position as researcher involved, rather than neutral (Frankenberg 1993, 30).

I now discuss my findings within the context of five themes. I first address the teachers' binary understanding of racism. Secondly, I discuss the perception of the SOR-SMC branding as presupposition. The third and fourth part illustrate how the interviewed teachers perpetuate a racist discourse in two specific ways: when they address "race", and when they talk about students of color. Finally, I evaluate the teachers' relation to whiteness and their responsibility as white educators.

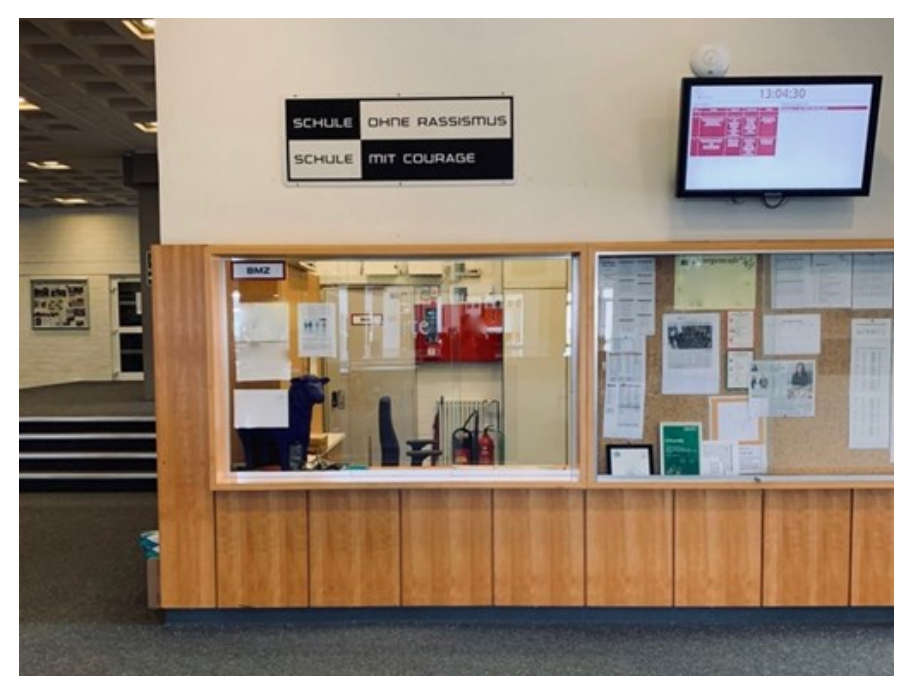

Figure 1: The 'School without Racism - School with Courage' sign at the Happiness School's entrance. Photo by author, 2020.

\section{On the Good Side of the Binary: "Every School Must Have That"}

The Happiness School attained the "award" (Auszeichnung), as the initiating teacher 
Mrs. Kessler phrased it, of being a SOR-SMC in 2013. This was celebrated with a ceremonial act in which a sign was mounted at the school's entrance (Figure 1). Its status was also referenced on the school's website. As the oldest teacher, Mr. Lindemann, who was involved in the school's Holocaust memorial excursions and various projects concerning discrimination, told me, they are proud of the accomplishment:

Well, we've certainly deserved it to be a "School without Racism"]. We've certainly deserved it. Basically, every school should have it, because it's not only the projects (laughs) that ... take up the topic. Basically, our everyday awareness is what this label stands for.

By saying "every school should have that" Lindemann argued that the positioning as a "School without Racism" is a necessity. He thereby emphasized his understanding of racism as bad and illustrated Trepagnier's (2001) argument that in dominant discourse, people differentiate between being racist and being not racist. Being racist is connected to individual, intended, and conscious actions, and therefore renders racist people as bad people (DiAngelo 2016). By understanding racism in these limited terms, being not-racist becomes the "default category," while racist actions are condemned (Trepagnier 2001, 142).

Lindemann's argument corresponds to the Western ideal of a tolerant and non-racist society (Lentin 2008). The dominant discourses in Europe uphold the modern values of equality and democracy as unique to the continent and thereby render any association with present racism as incompatible. Consequently, as can be exemplified by the above quotation, it is seen as self-evident to position oneself as nonracist in a "post-racial" society that has seemingly overcome racism (Lentin 2008). This perception aligns with a core concept behind SOR-SMC. The more than 3,300 "Schools without Racism" in Germany are required to collect signatures of at least $70 \%$ of the affiliated employees and students and subject their schools to the three pillars of the project: To develop sustainable projects against discrimination, to openly deal with discriminating acts and statements, and to exhibit at least one project a year concerning discrimination, especially racism. Thus, racism is portrayed as a conscious, voluntary but bad act executed by individuals. Only in cases of overt racism, students and teachers are advised to intervene (Aktion Courage e.V. n.d.-a).

This self-perception of the Happiness School as a "good" "School without Racism" is further shaped by the Christian profile of the school. When I asked Mrs. Döring, who recently started organizing the SOR-SMC projects, why the white students are so shocked to see or hear about racism she said that "most of the parents I met here are just very, very open people, who just in the end actually say that 'I want to treat every person as he deserves to be treated'. That sounds so big somehow, but who actually practice this Christian principle of altruism in some way". Unconsciously, Döring described the parents of the white children who "treat every person as he deserves to be treated." This implies a power hierarchy that renders white people as superior to people of color, who are perceived as the Other. The emphasis that the white parents "actually" practice what Döring understood to be principles of altruism highlights their moral superiority. But her understanding of altruism presupposes a judgement on the children's deservingness. Although well-intended, Döring reproduced "racial" inequality with her statement and highlighted the intersection of whiteness with Christianity (Arndt 2005).

It was a general assumption among the teachers that the majority of the students and staff at the Happiness School were white. But many justified this with being a Catholic school, which reinforced the perceived link between Christianity and whiteness that excludes many communities of Christian people of color. In 2015, the Happiness School voluntarily started to accept children who had recently fled to Germany. Some teachers believed that the school consequently showed a great diversity and was "very colorful" which reinforces the idea of Germanness as whiteness and renders people of color as "not-German-looking" (MingBao 2000, 175). The decision to accept the "international children" as they are called at the school was phrased as a humanitarian, "very generous" act by Mr. Richter, a teacher for Social Sciences, History and Economics. By 
calling them "refugee children" Richter further fed into the European discourse of rescuing the fleeing people that implies colonial power relations (Danewid 2017). Although the Happiness School is not explicitly bound to accept only Catholic students, the authority over the acceptance or refusal of children applied specifically to children that fell outside the norm of being white, Christian, and German students.

\section{Branding as Presupposition: Becoming a "School with Courage"}

The SOR-SMC project positions itself against any form of "discrimination, especially racism" (Aktion Courage e.V. n.d.-a, n.p.). The teachers at the Happiness School, too, conflated racism with prejudice and different forms of discrimination, such as homophobia. The second part of the SOR-SMC slogan, "School with Courage", was only added by the umbrella association in 2001 (Aktion Courage e.V. n.d.-b). Yet, by adopting a not-racist stance as the status quo, the latter part of the label became the focus of the Happiness School:

We were of the opinion that there is no racism as such at our school. (...) We have put the emphasis on 'School with Courage' and have looked at what possibilities we have at our school to draw attention to something. (...) We said that if we were to make this a topic, or yes, I wanted to, or the idea was: what is racism, everyday racism, or where do we encounter racism in books, in storybooks, in any kind of characters. Whether we would wake up sleeping dogs, and basically make it a topic if it is none.

With the first sentence, Kessler already presupposed that the school is racism-free, which inhibits any further engagement with racism as an institutional and structural issue. It illustrates silent racism, when racist connotations and structures remain unchallenged (Trepagnier 2001). Declaring it to be a 'School without Racism' proclaims absolute innocence and discharges the white teachers and students from an interrogation of their own position in a racist system. Instead, Kessler believed that by not addressing racism, they would prevent its reinforcement which is illustrative of the European silence on 'race' (Lentin 2008). Kessler told me that through travelling, especially on the African continent, she realized the problems associated with racism, which is why she was so passionate about the project. She used to go to bookstores and tell the staff about racist depictions in children's books. And recently, before our interview, she had been to a talk about everyday racism given by a Black journalist. As other teachers reported, there were very few individual instances of antisemitic jokes and one verbal attack against a girl of color. But the teachers dealt with them individually and usually found that the students had no bad intentions so that they were soon perceived to be resolved. Hence, the SOR-SMC branding still positions the school on the 'good' side of the binary, by claiming they are not racist (Trepagnier 2001). Once the schools commit themselves to be a SOR-SMC, there is no controlling mechanism that could reinsure that the school remains 'racism-free.'

It seems contradictory that the school consciously decided not to address racism. That presupposes that racism is not understood in its structural form. Otherwise, no school could be seen as operating outside a system that institutionally and structurally perpetuates racism. The choice not to talk about racism is a privilege for white people who can perceive an engagement with racism as a voluntary act (Mclntyre 1997). However, it shapes the lives of white people as well, and a discussion of it should not be an option, but a necessity (Frankenberg 1993). Unaware of this interpretation, Kessler emphasized her perceived detachment from racism:

... that we also did smaller projects for us that dealt less with racism but with things that were dear to our hearts. We did a day of politeness. Where we talked about manners. We put up posters everywhere. We really took a look at the old school again etiquette. Which parts of it make sense, which do not? We implemented a day of silence because noise is an issue here.

The quote indicates that racism, different from a day of politeness or silence, does not lie close to the hearts of the white teachers (and students). From a position of white privilege, Kessler assumed the universality of her 
perspective by talking about "projects for us" who are not affected by racism. She thereby neglected to acknowledge her advantaged position in a system built on 'racial' inequality and presented herself as unaware of students' experiences of racism. Being anti-racialist is seen as enough to position themselves as a 'good' school. Through various practices, the school's image of being 'good' and non-racist was upheld, whereby a deeper confrontation with its racist conditions was prevented. As the next section will show, especially because the systemic and institutional forms of racism were not challenged, the teachers at the Happiness School perpetuated a racist discourse.

\section{Talking about "Race": "For Me, They're Just the Children"}

During the first interviews, I assumed that the interviewees would know the terms People of Color (PoC) and Schwarze Deutsche (Black Germans) as they are used as self-designation in the German language, but they did not use either one. I then changed my strategy and asked the teachers whether they were familiar with the terms. Some teachers were familiar, while others had not heard the terminologies before. I only explained my understanding of the terms to the teachers unfamiliar with them, but retrospectively, I could have initiated a discussion about language with every teacher. Although I referred to "People of Color", the interviewees responded by saying colored people (Farbige), dark-skinned, black-skinned, "Colored People", or most frequently, "people with a migration background". However, the two teachers to whom I explained how and why I use "People of Color" appreciated the discussion and adapted to use the terminology for the remainder of the interview. Mrs. Krause, teacher for English and Social Sciences, showed reflection on her own lack of awareness and admitted that it is indeed important to keep up with the terminology to not discriminate against anyone. She further intended to "bring it up again" to create awareness through nondiscriminatory language, which showed the need to talk about the social construction of "races" as it is assumingly not done until yet. It indicates an insecurity about the use of language which arose out of the intention to be not-racist (Hondius 2014).
The interview with Mr. Neumann, one of the youngest teachers and a Happiness alumnus, illustrates the ambiguities of the terminology that was used for people of color. I asked him whether he had observed anything remarkable among the students concerning stereotypes, discrimination, or bullying, and he replied that, "I now teach many very, very high-performing classes, [and] I must say, there is simply a very large proportion of children without a migration background, and I believe that it [discrimination] is really less common there." Neumann associated the small number of people "with a migration background" with the absence of racism, which he defined as individual, mean-intended actions against people of color rather than structural racism (DiAngelo 2016; Trepagnier 2001). The quote further indicates a direct link between "very, very high-performing classes" and the absence of students "with a migration background". Asked about this potential link, Neumann confirmed and said, although one cannot generalize, children who recently fled to Germany are in a different position than someone who was born in that city and whose parents are doctors and lawyers. Apparently then, for Neumann, children "with a migration background" are not German, have a recent refugee history, and their parents lack prestigious occupations.

In dominant discourses, the phrase "with a migration background" is used for people of color generally, disregarding whether they recently migrated or whether their families have lived in Germany since generations. I asked Neumann if, from his perspective, a person of color who was born in Germany to a well-off family would also be considered a child "with a migration background":

Ah, that's a good question (...) I really don't like to make such distinctions, so who is from where and so on, for me they're just the children (laughs). (...) I think if they were born in Germany and their parents both speak German, they don't have a migration background, or, they don't have one anymore, do they? That's really difficult to differentiate. And actually, it is just so that, that I actually do not need it, only if you think about, it is already difficult right? 
Neumann thus revealed the contradictions of the terminology. "With a migration background" is one of the "alternatives to racial and racistsounding words" in the German language that are used to circumvent "race" (Hondius 2014, 275). However, it indicates an "implicit temporariness", thereby rendering people of color as the "racialized" Other who do not belong (Müller 2011, 627). Neumann used the terminology to prevent the implication of "races", which he "actually do[es] not need." Nevertheless, the teacher's direct association of academically high-performance students with "no migration background" illustrates his perception of differences among the children. It is therefore important to reflect upon the implications of such Othering terms. Neumann's example shows that the students are clearly not "just the children."

\section{Talking about Students of Color: Cultural Assumptions}

In the abstract, teachers like Mr. Richter believe in the ideal of cultural equality as a "very big gain." However, I found that their perceptions were biased by cultural expectations that solely focused on the students' difference. Echoing van den Broek's (2014) findings, the teachers emphasized the importance of cultural diversity. Yet they practiced exclusion through the limited and distorted interpretations of their observations that reaffirmed dominant European discourses on the "racialized" Others (El-Tayeb 2011). Their views were shaped by "perceptual distortion" and "selective perception" that gave only a fragmented view of the situation (van den Broek 2014).

When I asked Mr. Richter about the students of color at the school, he said that the image of "international children" has become increasingly normal: "However, also with all the difficulties. We as teachers notice that of course other cultures have also come to the school with children from other regions of the world, and so the things that were taken for granted in the past can no longer be taken for granted." Richter thereby implied that the German culture is homogeneous and is opposed to cultures from outside. With the example of one Syrian boy as a "problem student", Richter conflated culture, "race", and nationality. The particular boy showed disrespect for a female teacher who is a nun, which Richter interpreted by the cultural differences that the international student presumably had. His interpretation might be accurate. It is, however, significant that when I asked him about people of color at the school, his first association was "problematic" "international children", who brought different cultures and religions and deviant behavior that were incompatible with the assumed German standard. Later in the interview, Richter admitted some awareness of his own racist attitudes that he had towards Muslims:

I don't think it's right either, that modern women should wear a headscarf like that, yes, it always seems to me, like such a gesture of submission, that they represent themselves like this in the public. So, there I am sometimes shocked by myself, how I, how quickly I am with judgments.

That there were sentiments among the teachers especially about the presumably Muslim students is illustrative of dominant European discourses surrounding "race". El-Tayeb (2011) discussed how Muslim cultures are perceived as the antithesis to the European culture, an assumption that is deeply ingrained with the apparent gender inequality among Muslims. The headscarf is seen as the ultimate symbol of cultural difference, resembling "silenced, oppressed women living in parallel societies" (El-Tayeb 2011, 83). Although Richter proceeded to reflect upon his own biases, the assumption of cultural incompatibility is still underlying his interpretation of the Syrian boy's behavior as well as his understanding of the headscarf. The cultural discourse on the "European Others" places issues of gender inequality outside of Europe (El-Tayeb 2011). There were only a few girls at the Happiness School wearing headscarves, yet this provoked an internal debate and resulted in a minimum age rule for them to prevent "that the students pressure each other to wear these symbols." Certainly, the religious affiliation of the school impacted the school's discussion of Islam, but the implemented rule can still be understood as a form of patronization that interprets the wearing of a headscarf as bad. 
Asked about the segregating behavior of the students, Mrs. Kessler, the initiating teacher of the SOR-SMC project, discussed group formation in the context of the international classrooms. These were installed in German secondary schools to accommodate students who had recently migrated to Germany and needed additional support to adapt to the new language and environment (Ministerium für Schule und Bildung des Landes Nordrhein-Westfalen n.d.). Kessler was especially outspoken about the Syrian students, presumed to be the majority in the international classroom, whom the school started to accept in 2015:

That is such a Verclanisierung (clan in the making). They gang up and form a pretty powerful force over other students because they really stick together, I've noticed that and forwarded it to the responsible teacher [who is organizing the SOR-SMC projects] so that you don't get a two-class society or school.

With the use of a neologism that indicated the clan character of the students, Kessler interpreted the group as having a collective power. She perceived the situation from the perspective of the majority white students against the collective of the Syrian students. To "gang up" has very derogatory and negative connotations, expressing the lack of empathy that Kessler had for them. It also implied that it is a big group of students, which Kessler supported by describing them as executing a "pretty powerful force." She assumed the group character of the international classroom was a threat to the white students.

While Kessler offered one interpretation that made her scared and worried, there are other possibilities. Tatum's (1997) explanation of why black students tend to group together in a school context is very different. She argued that it is an act of empowerment and mutual support among students who have had similar experiences of discrimination. The Syrian students that Kessler mentioned recently migrated to Germany and took the same class; as such, it seems natural that they hung out together during breaks. Wellgraf (2014) also discussed how students find collective strategies that can be perceived as violent and dangerous, but these must be understood in the context of the "racial" and classist misrecognition that they experience.

Mrs. Kessler did not consider any of these alternative explanations. Instead, she proceeded to report the group formation to the SOR-SMC teacher, implying that something should be done about the Syrian students sticking together too closely. That Kessler interpreted the group of students in a specific way is indicative of "perceptual distortion" (van den Broek 2014). She focused on cultural difference as a possible threat, which rendered any alternative interpretation as invalid. Her fear of a "two-class society or school" became a self-fulfilling prophecy because Kessler already differentiated between two groups of students as outsiders and insiders.

\section{The Teachers' Role and Responsibility: "The Little Word "White"'"}

The previous section demonstrated the problems associated with branding a school to be without racism and illustrated ways in which institutionalized and subtle forms of racism were perpetuated at the Happiness School. While the SOR-SMC label was seen as an accomplishment, and the non-racist standing of the school as a necessity, the question arises as to how the teachers made sense of their role and responsibility as white teachers. Consequently, this section deals with the teachers' relationship to their whiteness.

Although the teachers found alternative racist and not racist-sounding words to talk about people of color, they were even more hesitant to talk about whiteness. When asked how he conceptualized "whiteness", Mr. Richter said:

I wouldn't use it too, because there will definitely be someone sitting in the class who feels excluded and who thinks, oh, I somehow belong to some tolerated minority here (...) and I'm trying to tell them that, trying to tell them no, there are no human races. This is a racist invention. And in that context, I'd rather not use the little word 'white'. 
Richter opposed an essentialist argument about "race" by arguing that "there are no human races," which he was eager to teach the students. To circumvent racist connotations, he employed a color-evasive strategy (Frankenberg 1993, 139). Richter saw his own whiteness as neutral and invisible. He also used the German diminutive for "word" (Wörtchen), which I translated to "little word", to belittle the word "white", thereby diminishing its significance as a social position in a racist society (Frankenberg 1993). His opposition to an essentialist argument had good intentions. He perceived whiteness as corresponding to white supremacy which he rejected as exclusionary (Müller 2011, 620). Instead of questioning why that could be the case, and thereby challenging any underlying racist structures, Richter was silent about whiteness. Although "racial" colorblindness is often seen as strategy to avoid essentialist racism, it reinforces white complicity because it does not address "racial" inequality (Frankenberg 1993, 145). With his response, Richter evaded the acknowledgement of his white privilege.

Most teachers had never thought critically about their whiteness before. Mr. Neumann said that he only recently realized that his class was comprised solely of white German students: "otherwise, I find it actually quite nice in everyday life, that you don't have to pay attention to it, or that, I think if you don't realize anymore, whether one is black or white, that's the right way. But that it is simply normal. That's what you want to achieve." With the intention that "race" should not matter, Neumann expressed his wish for "racial" colorblindness as "the right way." This is, however, contradictory, since he claimed it should be normal to have a diversity of "races", yet one should not notice if every single student was white. In an all-white German context, Neumann felt that "race" did not matter and he applied this to the general structure of "everyday life." He thus assumed that his white position was universal, implying that if whites experienced their "race" as insignificant then this must be true for everyone (DiAngelo 2016, 176). Such a claim denies the experiences of exclusion and structural racism that people of color face because they are not white. While in a racist system whiteness can go unnoticed, Neumann had previously pointed out his perception of how those "with a migration background" and low academic performance were interlinked. This contradiction emphasizes the importance of talking about "races" because apparently only whiteness is invisible, while the teachers emphasized the Otherness of people of color.

Mrs. Kessler told me about her travel experiences, and the benefits of whiteness in this context. When asked how this related to her experiences in Germany, she said:

So here I wouldn't know that I have an advantage now [as a white person]. I see it rather the other way around, that probably in conversations with colored people (sic) it would become apparent that they have a disadvantage. But I don't see the advantage now. I see it more on the African continent as a white person. Or in India or in other countries.

By focusing on disadvantaged positions of people of color, Kessler maintained her position as "race"-neutral (Frankenberg 1993). Whether the "racial" inequality is phrased as advantage or disadvantage is a matter of perspective, but a different emphasis can disguise the "racialized" position of white people. That being white is an "unearned advantage" (Mclntosh 1989, 11) in Germany remained invisible to Kessler especially because she rendered being white as the default category. Additionally, by comparing the situation to racism in other countries, Kessler downplayed the significance of racism in Germany and posed it as a problem that happens elsewhere. This is illustrative of Europe's denial of racism (Goldberg 2006), wherein colonialism is perceived as a problem external to Europe, which renders any problematization of its continuities in modern Europe impossible (Goldberg 2006). Kessler could refuse her responsibility as a white teacher because of the privileges she enjoyed. Racism in Germany therefore remained a problem for people of color in particular (Frankenberg 1993, 6).

The teachers' positions on whiteness must be understood as a spectrum. There is, for example, Mrs. Böhmer, who grew up in the German Democratic Republic and was involved in the school's excursions to the memorial site of Auschwitz. At the time of the interview, she 
was reading the book "Exit Racism" by Tupoka Ogette (2016) from whom I have taken the opening quote. She admitted that she learnt new aspects from the book, which she intended to integrate into her lessons. Böhmer further told me how she contextualized the German colonial past with class discussions of monuments and the history of the local zoo, as well as everyday examples of racism. However, she also admitted that she was more aware of racism because of her own experiences of discrimination as an East German woman in the West.

After I made explicit that critical whiteness is concerned with the position and responsibility of white people in a racist system, Mr. Freitag broadened his perception of this responsibility to ensuring values of democracy and tolerance in general:

But that now, that I would somehow have to take responsibility in the school, certainly in the sense of integration, or just massively oppose certain things, regardless of whether it is now bullying or ra-, or a form of racism, is actually self-evident. But I would not reduce that to just being white.

Freitag highlighted that in a global context he was aware of his privileges linked to wealth and political security. By conflating whiteness with a general global responsibility, a critical reflection on racism within Europe was again evaded. Specifically, he did not understand critical whiteness in the context of institutionalized and structural racism at the school. Rather, he perceived his responsibility as an abstract awareness, whereby concrete local interactions and structures remained unchallenged.

At this point, it is important to emphasize that the teachers were not defensive of their positions. Instead, throughout all the interviews, the teachers allowed me to offer my understanding of the situation and were open for a discussion. After having explained to her what critical whiteness entailed, Mrs. Krause said the following:

Otherwise, I wouldn't say that this whiteness is directly addressed in class, or at least (...) if, then these are probably conversations that simply result from a conversation with the students in class. But I wouldn't say that this is directly really being incorporated into our planned lessons, it might be something that could actually be extended. At least that's how I would perceive it personally.

Krause demonstrated reflection on her individual perception, but also on the lack of anti-racist education that the school is providing. She showed her concern about the topic and a willingness to achieve an anti-racist education.

\section{Conclusion}

In this case study, I have shown how a school that brands itself to be a "School without Racism" still perpetuated discrimination based on "race" through various practices. As Ogette (2016, 111) argued, "There are no schools without racism (yet)." In this regard, the SORSMC branding of the Happiness School seems to be counterproductive since it propagated anti-racialism that opposed "race" as a construct but did not tackle any underlying racist structures (Goldberg 2009, 10). The teachers I interviewed took the SOR-SMC branding for granted and assumed that the school was racism-free. They thereby engaged in silent racism and reproduced racist connotations and structures without challenging them (Trepagnier 2001).

The contradiction between the SOR-SMC branding and the teachers' perceptions and practices became especially clear when analyzing the school's position towards the "international children". Several teachers perceived the students of color at the school as non-German, lagging behind, and bringing along incompatible cultures. These individual accounts gave an indication on how "Germanness", whiteness, and Christianity appeared to be interlinked. Because they assumed their school to be not-racist, the teachers perpetuated a racist discourse. Being unaware of their white privilege, the teachers evaded a confrontation with their responsibility as white educators.

The results of this study have certain limitations. I reduced the sample size to only nine teachers at a Catholic comprehensive school in a conservative, predominately white city in West Germany. The selection of the teachers was limited to their involvement with 
the SOR-SMC branding and the subjects English, History, and Social Sciences. Except for one meeting in person, the interviews were limited to videocalls. This required me to rely on the participants' own reflection of their actions, whereby many aspects of silent racism might have remained unnoticed. Further research should therefore integrate participant observation at the school and inside the classroom. Additionally, this research indicated the intersection of different social categories such as "race", class, and religion. For the future, it would be beneficial to focus on an intersectional perspective to provide a multilayered account on discrimination at German schools.

Taking the SOR-SMC branding seriously would imply "looking closely instead of looking away" (Ogette 2016, 111). Teachers have a crucial role in combatting the institutionalization of racism at German schools. Therefore, white teachers need to understand that talking about racism is not a choice but a necessity, and the SOR-SMC branding could be a good starting point. Being anti-racist is not accomplished by declaring a school as racism-free. Instead, anti-racism involves a deeper engagement with the structures that keep "racial" inequality in place (Goldberg 2009, 10). The SOR-SMC project group could be realized as a platform for students of color to find empowerment and for white teachers and students to learn about the institutional and structural dimensions of racism at their school. This could be an important first step in the process of becoming a "School against Racism". 


\section{Acknowledgements}

I would like to thank the nine participating teachers for their time and sharing their personal insights with me. This study would not have been possible without you and I am very grateful for your trust. I owe special thanks to my supervisor Dr. Ulrike Mueller. Thanks for your continuous support, your feedback, your words of encouragement, and your expertise. Last but not least, I would like to thank Dr. Martha Radice and the editors of the JUE who made my first publication a very pleasant and enriching experience. 


\section{References}

Aktion Courage. e.V. n.d.-a. "10 Fragen - 10 Antworten." https:// www.schule-ohne-rassismus.org/mitmachen/weitere-tipps-at/.

---. n.d.-b. "25 Jahre Schule ohne Rassismus - Schule mit Courage." https://www.schule-ohne-rassismus.org/netzwerk/ bundeskoordination/25jahre/.

---. n.d.-c. "Schule ohne Rassismus: Trägerverein." https://www.schule -ohne-rassismus.org/traegerverein/.

Applebaum, Barbara. 2004. "Social Justice Education, Moral Agency, and the Subject of Resistance." Educational Theory 54 (1): 59-72.

Apraku, Josephine. 2017. "Zur Bedeutungsverschiebung des rassistischen Diskurses in Geschichtsschulbüchern der Sekundarstufe II in der Bundesrepublik Deutschland zwischen 1970 und 2010." Institut für diskriminerungsfreie Bildung IDB.

Arndt, Susan. 2005. "Weißsein. Die verkannten Strukturenkategorie Europas und Deutschlands." In Mythen, Masken und Subjekte. Kritische Weißseinsforschung in Deutschland, edited by Maureen Maisha Eggers, Grada Kilomba, Peggy Piesche and Susan Arndt, 24-30. Münster: Unrast.

Bundesamt für Migration und Flüchlinge. 2019. Migrationsbericht 2018 - Kapitel 7: Personen mit Migrationshintergrund in Deutschland. https://www.bamf.de/SharedDocs/Anlagen/DE/ Forschung/Migrationsberichte/migrationsbericht2018. pdf;jsessionid=1 C65EB3BC9F9C25F7B79F41D34E03BB0.inte rnet282?_blob=publicationFile $\& v=16$

Danewid, Ida. 2017. "White Innocence in the Black Mediterranean: Hospitality and the Erasure of History." Third World Quarterly 38 (7): 1674-1689.

DiAngelo, Robin J. 2016. What does it mean to be white?: Developing white racial literacy. New York: Peter Lang.

Eggers, Maureen Maisha, Grada Kilomba, Peggy Piesche, and Susan Arndt. 2005. Mythen, Masken und Subjekte. Kritische Weißseinsforschung in Deutschland. Münster: Unrast.

El-Tayeb, Fatima. 2011. European Others: Queering Ethnicity in Postnational Europe. Minneapolis, MN: University of Minnesota Press. 
ENAR European Network Against Racism. 2017. Racism and Discrimination in Employment in Europe. ENAR Shadow Report 2013-2017. https://www.enar-eu.org/IMG/pdf/ shadowreport_2016x2017_long_final_lowres.pdf.

Fereidooni, Karim. 2016. “Diskriminierungs-und Rassismuserfahrungen von Referendar*innen und Lehrer*innen 'mit Migrationshintergrund' im deutschen Schulwesen. Eine quantitative und qualitative Studie zu subjektiv bedeutsamen Ungleichheitspraxen im Berufskontext." Doctoral Dissertation, Fakultät für Verhaltens- und Empirische Kulturwissenschaften, Ruprecht-Karls-Universitaet. https://archiv.ub.uni-heidelberg.de/ volltextserver/20203/1/Dissertation\%20Karim\%20Fereidooni (1).pdf.

Frankenberg, Ruth. 1993. White Women, Race Matters: The Social Construction of Whiteness. Gender, Racism, Ethnicity. London: Routledge.

Fuchs, Dana, and Laura Frey. 2010. “Erschlagen vom Nazi-Mob, während die Polizei zusah. Zwanzigster Todestag von Amadeu Antonio Kiowa." Bell Tower, November 24, 2010. https:// www.belltower.news/erschlagen-vom-nazi-mob-waehrend-diepolizei-zusah-zwanzigster-todestag-von-amadeu-antonio-kiowa32986/.

Goldberg, David Theo. 2006. "Racial Europeanization." Ethnic and Racial Studies 29 (2): 331-364.

---. 2009. The Threat of Race: Reflections on Racial Neoliberalism. Malden, MA: Wiley-Blackwell.

Gomolla, Mechtild, and Frank-Olaf Radtke. 2009. Institutionelle Diskriminierung. Die Herstellung ethnischer Differenz in der Schule. 3rd ed. Wiesbaden: VS Verlag für Sozialwissenschaften.

Gray, David E. 2014. Doing Research in the Real World. London: SAGE Publications.

Ha, Kien Nghi. 2009. "'’'People of Color" als solidarisches Bündnis." Migrazine. http://www.migrazine.at/artikel/people-color-alssolidarisches-bundnis.

Hesse-Biber, Sharlene Nagy, and Patricia Leavy. 2006. The Practice of Qualitative Research. Thousand Oaks: SAGE Publications. 
Hondius, Dienke. 2014. “Black Dutch Voices: Reports from a Country that Leaves Racism Unchallenged." In Dutch racism, edited by Philomena Essed and Isabel Hoving, 273-294. Amsterdam: Rodopi B.V.

Kaschel, Helena. 2020. "Shootings in Hanau: 'We Aren't Safe Anywhere."' Deutsche Welle, February 21, 2020. https:// www.dw.com/en/shootings-in-hanau-we-arent-safe-anywhere/a52454259.

Klemm, Klaus. 2007. "Ethnische und soziale Herkunft: entscheidend für den Schulerfolg? Reformbedarf des Bildungssystems." Schule in der Einwanderungsgesellschaft. Gesprächskreis Migration und Integration. Dokumentation im Auftrag der Friedrich-EbertStiftung. 8-17. http://library.fes.de/pdf-files/asfo/04689.pdf.

Lentin, Alana. 2008. "Europe and the Silence about Race." European Journal of Social Theory11 (4): 487-503.

Marmer, Elina, and Papa Sow. 2015. "Wie Rassismus aus

Schulbüchern spricht." Kritische Auseinandersetzung mit "Afrika"Bildern und Schwarz-Weiß-Konstruktionen in der Schule Ursachen, Auswirkungen und Handlungsansätze für die pädagogische Praxis, Wienheim: Beltz.

McIntosh, Peggy. 1989. "White Privilege: Unpacking the Invisible Knapsack." Peace and Freedom, July/August: 10-12.

McIntyre, Alice. 1997. "White Talk." In Making Meaning of Whiteness: Exploring Racial Identity with White Teachers, 45-69. Albany: State University of New York Press.

Ming-Bao, Yue. 2000. “On not Looking German: Ethnicity, Diaspora and the Politics of Vision." European Journal of Cultural Studies 3 (2): 173-194. https://doi.org/10.1177/136754940000300202.

Ministerium für Schule und Bildung des Landes NordrheinWestfalen. n.d. "Integration durch Bildung." https:// www.schulministerium.nrw.de/themen/schulsystem/integrationdurch-bildung.

Müller, Ulrike Anne. 2011. “Far Away so Close: Race, Whiteness, and German Identity." Identities 18 (6): 620-645.

Ogette, Tupoka. 2016. Exit RACISM. Münster: Unrast Verlag. 
Picower, Bree. 2009. "The Unexamined Whiteness of Teaching: How White Teachers Maintain and Enact Dominant Racial Ideologies." Race, Ethnicity and Education 12 (2): 197-215.

Radtke, Frank-Olaf. 2007. "Segregation im deutschen Schulsystem." In Was heißt hier Parallelgesellschaft?: Zum Umgang mit Differenzen, edited by Claudia Nikodem Wolf-Dietrich Bukow, Erika Schulze, and Erol Yildiz, 201-212. Wiesbaden: VS Verlag für Sozialwissenschaften.

Tatum, Beverly Daniel. 1997. Why are all the Black Kids Sitting Together in the Cafeteria? And Other Conversations about Race. New York: Basic Books.

Trepagnier, Barbara. 2001. "Deconstructing Categories: The Exposure of Silent Racism." Symbolic Interaction 24 (2): 141-163. https:// doi.org/10.1525/si.2001.24.2.141.

van den Broek, Linda. 2014. "Neither With, nor Without ThemEthnic Diversity on the Work Floor: How Egalitarianism Breeds Discrimination." In Dutch racism, edited by Philomena Essed and Isabel Hoving, 255-271. Amsterdam: Rodopi B.V.

Wellgraf, Stefan. 2014. “Facing Contempt: Dealing with Exclusion among Berlin Hauptschüler." Ethnography 15 (2): 160-183. 